\title{
Germline DNA copy number variation in familial and early-onset breast cancer
}

\author{
Ana CV Krepischi ${ }^{1,2^{*}}$, Maria Isabel W Achatz ${ }^{1,2}$, Erika MM Santos ${ }^{1}$, Silvia S Costa ${ }^{3}$, Bianca CG Lisboa', \\ Helena Brentani ${ }^{4}$, Tiago M Santos, Amanda Gonçalves ${ }^{1}$, Amanda F Nóbrega', Peter L Pearson ${ }^{3}$, \\ Angela M Vianna-Morgante ${ }^{3}$, Dirce M Carraro ${ }^{1,2}$, Ricardo R Brentani ${ }^{1,2}$ and Carla Rosenberg ${ }^{3}$
}

\begin{abstract}
Introduction: Genetic factors predisposing individuals to cancer remain elusive in the majority of patients with a familial or clinical history suggestive of hereditary breast cancer. Germline DNA copy number variation (CNV) has recently been implicated in predisposition to cancers such as neuroblastomas as well as prostate and colorectal cancer. We evaluated the role of germline CNVs in breast cancer susceptibility, in particular those with low population frequencies (rare CNVs), which are more likely to cause disease."

Methods: Using whole-genome comparative genomic hybridization on microarrays, we screened a cohort of women fulfilling criteria for hereditary breast cancer who did not carry BRCA1/BRCA2 mutations.

Results: The median numbers of total and rare CNVs per genome were not different between controls and patients. A total of 26 rare germline CNVs were identified in 68 cancer patients, however, a proportion that was significantly different $(P=0.0311)$ from the control group (23 rare CNVs in 100 individuals). Several of the genes affected by CNV in patients and controls had already been implicated in cancer.

Conclusions: This study is the first to explore the contribution of germline CNVs to BRCA1/2-negative familial and early-onset breast cancer. The data suggest that rare CNVs may contribute to cancer predisposition in this small cohort of patients, and this trend needs to be confirmed in larger population samples.
\end{abstract}

\section{Introduction}

It has been estimated that all known cancer susceptibility genes account for only $1 \%$ to $15 \%$ of familial cancers $[1,2]$. Approximately $5 \%$ to $10 \%$ of hereditary breast and ovarian cancers result from dominant mutations in known single genes [3-6], particularly BRCA1/BRCA2. Therefore, the basis for a large fraction of genetic predisposition in families with breast and/or ovarian cancer remains to be uncovered.

Recent studies have highlighted DNA copy number variation $(\mathrm{CNV})$ as the most prevalent type of structural variation in the human genome [7-9], and its role in normal development and disease has been demonstrated through its impact on gene expression and protein structure [10-13]. In particular, CNVs involving

\footnotetext{
* Correspondence: ana.krepischi@gmail.com

'National Institute of Science and Technology in Oncogenomics, AC

Camargo Hospital, Rua Taguá 440, 01508-010, São Paulo, Brazil

Full list of author information is available at the end of the article
}

deletions have been reported as a cause of cancer susceptibility, occurring in up to $30 \%$ of highly penetrant cancer-predisposing genes, including BRCA1, BRCA2, $A P C, S M A D 4$ and TP53, as well as mismatch repair genes [14-16] (reviewed in [17,18]).

Germline gains and losses of large DNA segments have recently been reported as factors predisposing individuals to neuroblastoma, prostate and colorectal cancer and BRCA1-associated ovarian cancer [19-24]. Nevertheless, whole-genome $\mathrm{CNV}$ profiling of patients fulfilling criteria for hereditary breast and ovarian cancer, but without BRCA1/BRCA2 mutations, has not been reported. In the present study, we investigated the germline CNV profiles of 68 unrelated familial and earlyonset breast cancer patients who were negative for $B R C A 1 / B R C A 2$ mutations, with the aim of detecting new genes contributing to breast and/or ovarian cancer predisposition.

\section{Biomed Central}




\section{Materials and methods Study approval}

The research protocol was approved by the ethics committee of the AC Camargo Cancer Hospital, São Paulo, Brazil (protocol 1175/08), and informed consent was obtained from the subjects.

\section{Patients}

Samples of peripheral blood cells for DNA extraction were collected after informed consent was obtained from 68 women attending the AC Camargo Cancer Hospital prior to any systemic treatment. They were selected for fulfilling at least one of the criteria for hereditary breast and ovarian cancer published in the National Comprehensive Cancer Network Practice Guidelines in Oncology version 1.2010 [25].

Confirmation of the family history of cancer was obtained whenever possible on the basis of pathology reports, medical records and/or death certificates. All women had previously tested negative for BRCA1/ $B R C A 2$ pathogenic mutations (based on Sanger sequencing of coding sequences). Because most of the affected relatives were already dead, were inaccessible or refused to participate, we were unable to investigate $\mathrm{CNV}$ segregation in the majority of the cases.

The criteria used to select patients, type of cancer, and age at cancer diagnosis are given in Additional file 1. Most of the patients $(n=48)$ were familial cases of hereditary breast and/or ovarian cancer in which at least one other family member was affected. The remaining 20 patients were considered hereditary breast and/or ovarian cancer patients for being isolated cases of early-onset cancer ( $\leq$ 45 years of age). Most of the tumors were invasive ductal breast carcinomas. Aside from two patients who had only ovarian cancer (patients 9 and 34), all of the other sixty-six patients had breast cancer (bilateral in patient 67, and patients 10 and 16 also had ovarian cancer).

\section{Control sample}

DNA samples were obtained from the peripheral blood cells of control participants after their informed consent was obtained. One hundred DNA samples (seventy-eight women and twenty-two men) were provided by the Genetic Center of the Institute of Biosciences, University of São Paulo, São Paulo, Brazil. They were obtained from noncarrier relatives of patients affected by mental impairment with clear genetic etiology unrelated to cancer predisposition (namely, fragile $\times$ syndrome or de novo chromosomal rearrangements). No information regarding their cancer history was available. Age-matching of controls and patients was considered unnecessary for this study since CNV frequency in blood is generally considered stable and unrelated to chronological age.

\section{Comparative genomic hybridization based on microarray (array-CGH)}

We performed comparative genomic hybridization based on microarray (array-CGH) using a $180 \mathrm{~K}$ whole-genome platform (design 22060; Agilent Technologies, Santa Clara, CA, USA), which has an average probe spacing of $18 \mathrm{~kb}$. Briefly, samples were labeled with Cy3and Cy5-deoxycytidine triphosphates by random priming. Purification, hybridization and washing were carried out as previously reported [26,27]. Scanned images of the arrays were processed using Feature Extraction software (Agilent Technologies).

We applied the Genomic Workbench software (Agilent Technologies) for calling DNA CNV using the aberration detection method 2 statistical algorithm with a sensitivity threshold of 6.7. Poor quality hybridization (QC > 0.3) was disregarded. Duplication or deletion of genomic segments was considered when the $\log _{2}$ ratio of the Cy3/Cy5 intensities of a given region encompassing at least three probes was $>0.3$ or $<-0.3$, respectively. All hybridizations were gender-matched and processed in reverse-labeling duplicates as described previously [28]. CNVs that were not detected in both experiments were disregarded.

\section{Copy number validation by real-time PCR}

Selected CNVs detected in the patient group were validated by real-time quantitative PCR (qPCR) [29] using the SYBR Green system (Roche Applied Science, Indianapolis, IN, USA) on a 7500 Fast Real-Time PCR System apparatus (Applied Biosystems, Foster City, CA, USA). As controls or for copy number calibration, we used three DNA samples obtained from healthy donors and the qPCR values for the GAPD and HPRT genes for normalization. All samples were run in duplicate, and the data were analyzed with Microsoft Excel software (Microsoft Corp, Redmond, WA, USA) using the comparative $\Delta \Delta^{\mathrm{C}}{ }_{\mathrm{t}}$ cycle threshold method (Applied Biosystems), which assumes that the calibrator DNA has two copies of the control genes.

\section{Data analysis}

Detected CNVs were compared to CNV data from oligoarray studies documented in the Database of Genomic Variants (DGV) [30]. We classified the CNVs into "rare" and "common," with rare being those that encompassed coding sequences which had never been documented as variable in the general population (DGV). CNVs were evaluated regarding proportion of total and rare CNVs, frequency of deletions and duplications, length, and gene content using the Mann-Whitney $U$ test and Fisher's exact test.

Gene annotation was performed using the University of California Santa Cruz Genome Browser (UCSC) [31], 
BioMart in the Ensembl Genome Browser [32] and Catalog of Somatic Mutations. We investigated the biological features of genes contained within the rare CNVs using GOTree Machine (GOTM) software [33] to measure the enrichment in the Gene Ontology (GO) and Kyoto Encyclopedia of Genes and Genomes (KEGG) categories. GOTM reports only those enrichments that are statistically significant as determined by the hypergeometric test [34].

\section{Results}

Full CNV data on the controls and patients can be found in Additional file 2. A whole extra copy of the $x$ chromosome was identified in one patient. This chromosomal numerical alteration was not considered a $\mathrm{CNV}$. The array-CGH results are summarized in Table 1. We found a total of $1,238 \mathrm{CNVs}$ in 168 individuals. CNVs observed in both patient and control samples corresponded to $81.3 \%$ of the total, all of which overlapped common CNVs (DGV). CNVs detected exclusively in one of the groups corresponded to 110 events in patients and 121 in controls. The distribution of CNVs did not differ between patients and controls $(P=0.1724$, Mann-Whitney $U$ test).

Only 49 of the 1,238 CNVs could be classified as rare, and none of them were recurrent. Those CNVs classified as rare based on DGV data corresponded to $4 \%$ (49 of $1,238 \mathrm{CNVs}$ ) of all CNVs detected in our study. The $\log _{2}$ ratios of the rare CNVs (all outside the $\log _{2}-0.65$ to $\log _{2} 0.45$ range) were not suggestive of mosaicism, indicating that these CNVs are likely constitutive. In the control group, 3.28\% (23 of 702) of CNVs detected in 23 of 100 individuals (23\%) were classified as rare, whereas 26 of 536 rare CNVs (4.85\%) were found in 25 of 68 patients $(37 \%)$. The median numbers of total and rare CNVs per genome did not differ between controls and patients. However, the proportion of rare CNVs in patients was higher than in the controls $(P=0.0311$, Fisher's exact test). The relative frequencies of duplications and deletions among rare CNVs were similar between controls (14 duplications and 9 deletions) and patients (14 duplications and 12 deletions).

Table 1 Summary of DNA copy number variation data from breast and/or ovarian cancer patients and controls ${ }^{a}$

\begin{tabular}{lcc}
\hline Copy number variation & $\begin{array}{c}\text { Controls }(\boldsymbol{n}= \\
\mathbf{1 0 0})\end{array}$ & $\begin{array}{c}\text { Patients }(\boldsymbol{n}= \\
\mathbf{6 8})\end{array}$ \\
\hline Total CNVs & 702 & 536 \\
Rare variants & 23 & 26 \\
$\quad$ Deletions & 9 & 12 \\
$\quad$ Duplications & 14 & 14 \\
Median CNVs per individual & $7.0(4$ to 9$)$ & $7.5(5$ to 10) \\
$(\mathrm{IQR})^{\mathrm{b}}$ & & \\
\hline
\end{tabular}

${ }^{\mathrm{a}} \mathrm{CNV}=$ copy number variation. ${ }^{\mathrm{b}} \mathrm{IQR}=$ interquartile range.
We also inspected the rare CNVs for length and gene content (Table 2). The length of rare CNVs in controls and patients did not differ significantly. The lengths of rare deletions or duplications did not differ between patients and controls or within the patient group alone. However, only in the control group were the deletions found to be significantly smaller than the duplications ( $P=0.0089$, Mann-Whitney $U$ test).

The 26 rare CNVs and the affected genes detected in patients are described in Table 3 . The published literature regarding those genes already reported to be altered in cancer is listed in Additional file 3. The rare CNVs identified in the control group are listed in Additional file 4 . To evaluate whether the rare CNVs detected among cancer patients represent common CNVs in the Brazilian population, we compiled CNV data obtained from independent samples studied in our laboratory using $180 \mathrm{~K}$ array-CGH. These individuals (120 females and 38 males) were selected on the basis of criteria other than cancer history, including 52 patients with dementia, 56 cases of nonsyndromic hearing loss and 51 cases of Müllerian anomalies (C Rosenberg; ACV Krepischi; unpublished data). None of the rare $\mathrm{CNVs}$ documented in this study were detected in these independent cohorts of patients.

In one family, the patient with early-onset breast cancer (patient 3), as well as her affected sister, who presented with breast cancer at 28 years of age, were found to carry a $540 \mathrm{~kb} 1 \mathrm{p} 31.1$ microdeletion (Figure 1A). The heterozygous deletion was confirmed in the two affected sisters by qPCR. In the second family, a $90 \mathrm{~kb}$ microdeletion at Xq25 was detected in two affected sisters, one of whom presented with bilateral breast cancer (patient 17).

Figure 1 depicts two additional rare CNVs identified by array-CGH and validated by qPCR in unrelated patients. Figure $1 \mathrm{~B}$ shows a $137 \mathrm{~kb}$ deletion at 9p21.3 detected in patient 13 . Figure $1 \mathrm{C}$ illustrates a $640-\mathrm{kb}$ duplication mapped at Xq13.1 (patient 27).

We characterized the function of genes located in rare CNVs in both patients and controls by GO term and KEGG pathway analysis using the Gene Ontology Tree Machine. We did not detect any significant difference in gene content in either patients or controls.

\section{Discussion}

We used array-CGH to investigate the role of rare germline CNVs in probands of individuals with a familial history of breast and ovarian cancer. Because evaluation of CNV profiles depends on ethnic background, array platform and method of analysis [35-38], all experiments were performed using the same platform, the same analytical parameters and a Brazilian control group. We disregarded the possibility that the CNVs 
Table 2 Size and gene content of rare copy number variations ${ }^{a}$

\begin{tabular}{lcc}
\hline Rare CNVs & Control group $(\boldsymbol{n}=\mathbf{2 3} \mathbf{C N V s})$ & Patient group $(\boldsymbol{n}=\mathbf{2 6}$ CNVs) \\
\hline Length range $(\mathrm{kb})$ & 31 to 684 & 32 to 1,592 \\
Median size $(\mathrm{IQR})^{\mathrm{b}}(\mathrm{kb})$ & $225.5(125.8$ to 275.3$)$ & $136.7(70.3$ to 278.0$)$ \\
Deletions $(\mathrm{kb})$ & $127.2(43.7$ to 225.5$)$ & $145.0(124.6$ to 229.5$)$ \\
Duplications $(\mathrm{kb})$ & $249.5(202.9 .4$ to 350.4$)$ & $119.2(50.0$ to 278.0$)$ \\
Gene number/individual & $0.4(44$ of 100$)$ & $0.8(57$ of 68$)$ \\
\hline
\end{tabular}

${ }^{\mathrm{a}} \mathrm{CNV}=$ copy number variation. ${ }^{\mathrm{b}} \mathrm{IQR}=$ interquartile range.

were somatically acquired because none of the results were suggestive of mosaicism. Furthermore, the limited data available indicate that $\mathrm{CNV}$ profiles are rather stable in adult tissues (reviewed in [39]).

Common CNVs often contain cancer-related genes and likely play a role in carcinogenesis [40]. However, only a minority of CNVs, those with low population frequencies (rare CNVs), would be likely to contain genes that are highly penetrant genetic factors for disease susceptibility, including cancer $[7,41]$. In our study, the median numbers of total and rare CNVs per genome were quite similar in patients and controls, reflecting a lack of genomic instability in this cohort of patients.
These results are in agreement with data derived from a study of BRCA1-associated ovarian cancer patients [42]. Nevertheless, the patients did present a higher proportion of rare CNVs compared to controls. None of these rare CNVs were present in an independent cohort of more than 150 individuals, providing support for their nonpolymorphic nature in the Brazilian population. Assuming that some of these rare CNVs are cancerrelated, the patients would carry an increased cancer risk proportionate to the number of rare genomic imbalances. The reason why we found a greater proportion of rare CNVs in patients than in controls is not clear. We could speculate that deleterious $\mathrm{CNVs}$ tend to be

Table 3 Genomic positions (build 36-Hg18), size, type and affected genes of the 26 rare copy number variations identified in patients ${ }^{a}$

\begin{tabular}{|c|c|c|c|c|c|c|}
\hline Chromosome & Cytoband & Start site & Size (bp) & CNV type & Gene Names & Patient \\
\hline chr1 & p31.1 & $76,801,602$ & 550,723 & del & ST6GALNAC3, ST6GALNAC5, PIGK & 3 \\
\hline chr1 & q44 & $243,610,556$ & 153,230 & del & KIF26B & 16 \\
\hline chr1 & p32.1 & $59,559,568$ & 41,339 & del & FGGY & 15 \\
\hline chr2 & p25.1 & $9,165,985$ & 192,606 & del & ASAP2 & 21 \\
\hline chr2 & $\mathrm{q} 22.2$ & $143,463,273$ & 300,408 & dup & KYNU, ARHGAP15 & 7 \\
\hline chr2 & q32.2 & $190,015,149$ & 45,366 & dup & WDR75 & 28 \\
\hline chr3 & p24.3 & $18,759,412$ & 635,060 & dup & KCNH8, MIR4791 & 11 \\
\hline chr3 & $q 28$ & $193,405,249$ & 135,458 & dup & FGF12 & 1 \\
\hline chr4 & q31.3 & $152,508,270$ & 136,605 & del & FAM160A1 & 29 \\
\hline chr6 & p12.1 & $55,468,168$ & 33,031 & dup & HMGCLL1 & 30 \\
\hline chr9 & p21.3 & $20,661,515$ & 136,814 & del & KIAA1797, MIR491 & 13 \\
\hline chr9 & p24.1 & 5,130,196 & 168,153 & del & INSL6, INSL4, RLN2 & 20 \\
\hline chr9 & q31.3 & $111,832,790$ & 340,164 & del & PALM2-AKAP2, AKAP2, C9orf152, TXN, TXNDC8, SVEP1 & 22 \\
\hline chr10 & p13 & $16,970,291$ & 103,018 & dup & CUBN & 19 \\
\hline chr11 & q12.3 & $62,290,497$ & 38,091 & dup & POLR2G, TAF6L, TMEM179B, TMEM223, NXF1 & 25 \\
\hline chr16 & q23.3 & $81,315,382$ & 136,618 & del & $\mathrm{CDH} 13$ & 5 \\
\hline chr16 & $q 11.2$ & $45,058,042$ & 198,742 & dup & ANKRD26P1, SHCBP1, VPS35 & 6 \\
\hline chr17 & $\mathrm{q} 25.1$ & $71,478,161$ & 33,362 & dup & ACOX1, TEN1, CDK3 & 5 \\
\hline chr18 & q12.1 & $27,990,329$ & 64,132 & dup & MEPIB & 18 \\
\hline chr21 & q21.3 & $29,391,572$ & 496,425 & del & C21orf7, LINC00189, BACH1, GRIK1 & 8 \\
\hline chr21 & $\mathrm{q} 22.3$ & $46,538,913$ & 210,594 & dup & YBEY, C21orf58, PCNT, DIP2A & 12 \\
\hline chrX & $\mathrm{q} 22.3$ & $109,193,988$ & 31,659 & del & TMEM164, MIR3978 & 23 \\
\hline $\operatorname{chrX}$ & $\mathrm{q} 25$ & $126,971,799$ & 88,694 & del & ACTRT1 & 17 \\
\hline $\operatorname{chr} r$ & q13.1 & $68,398,248$ & 639,366 & dup & FAM155B, EDA & 27 \\
\hline $\operatorname{chrX}$ & p22.31 & $6,499,677$ & $1,592,274$ & dup & HDHD1, STS, VCX, PNPLA4 & 15 \\
\hline $\operatorname{chr} x$ & q13.3 & $75,294,586$ & 88,796 & dup & CXorf26 & 14 \\
\hline
\end{tabular}

${ }^{\mathrm{a}} \mathrm{CNV}=$ copy number variation; del = deletion; dup = duplication. 

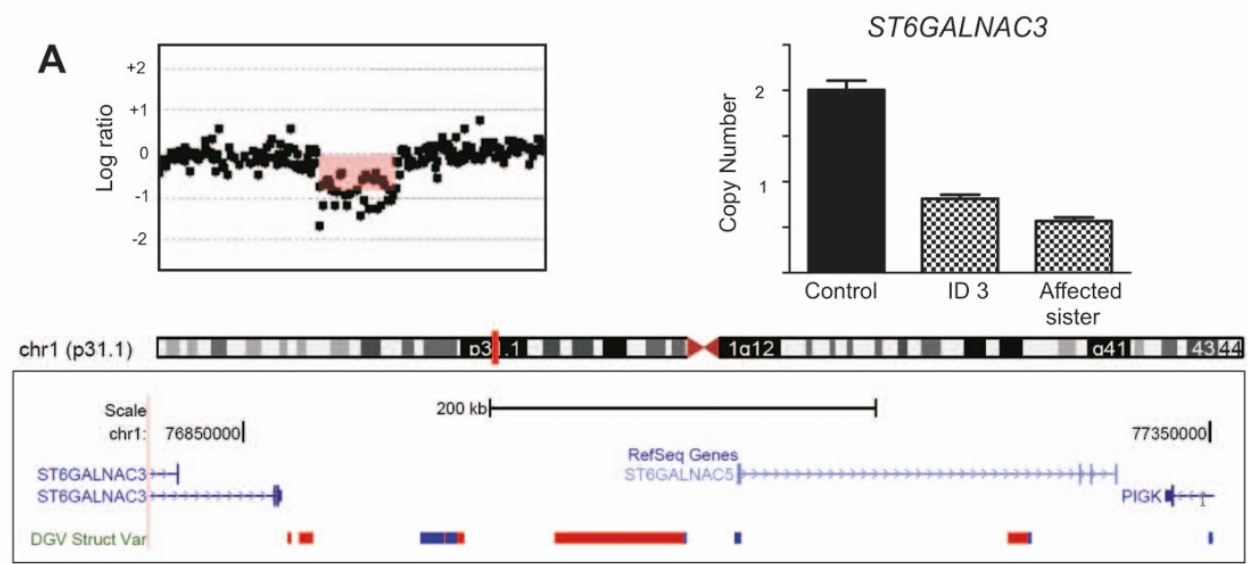

\section{B}
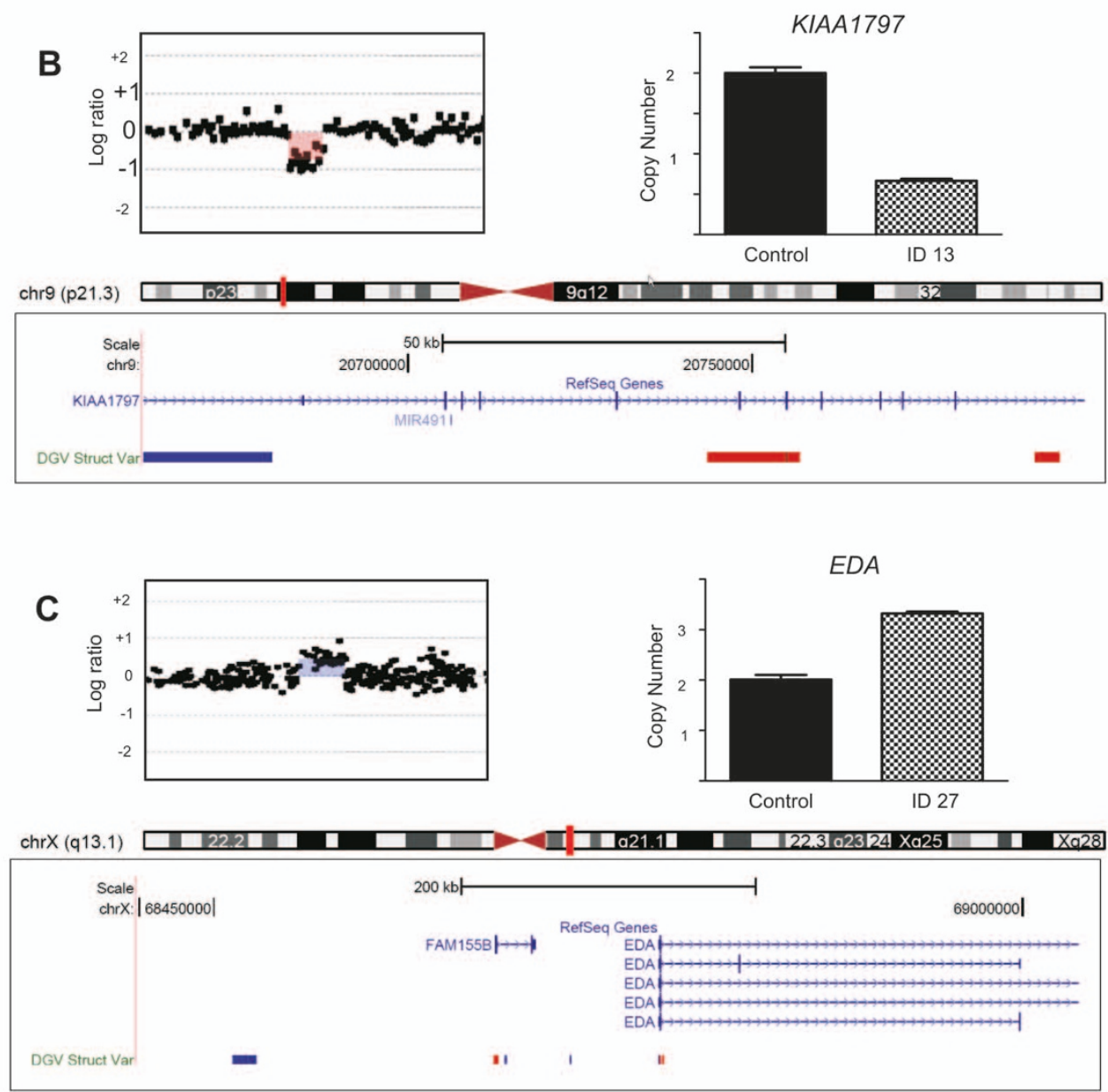

Figure 1 Rare germline copy number variations detected in three unrelated breast cancer patients. (A) to (C) Top panels exhibit the array comparative genomic hybridization profiles of the chromosome regions (images based on the Genomic Workbench software) containing the selected copy number variation (CNV) (left) and the copy number of the corresponding sequences assessed by quantitative PCR in patients 3, 13 and 27 and control individuals (right). Bottom panels show the CNV positions in the chromosomes (small vertical red bars in the ideograms) and the corresponding genomic segments. The encompassed genes according to the Reference Sequence (RefSeq) collection are indicated by blue lines in the RefSeq genes track, and the CNVs loci reported in the general population are indicated by the blue (gain) and red (loss) bars in the Database of Genomic Variants (DGV) Struct Var track (data retrieved from the DGV) (images derived from the UCSC Genome Browser, freeze October 2011). Part (A) shows microdeletion at 1 p31.1 of a $540 \mathrm{~kb}$ genomic segment containing the sequences of three genes. This alteration cosegregated with early-onset breast cancer in patient 3 and her sister. Part (B) shows microdeletion at 9p21.3 of a $137 \mathrm{~kb}$ genomic segment encompassing the gene KIA1797 and the microRNA MIR491 (patient 13). Part (C) shows microduplication at Xq13.1 of a 640 kb genomic segment affecting the FAM155B and EDA genes (patient 27). 
eliminated and, for some reason, conceivably less efficient apoptosis or DNA repair mechanisms, this selection would be less stringent in these patients. Whatever the reason may be, the connection between this finding and the patients' phenotypes deserves investigation.

Part of the rare genomic imbalances harbors genes that could potentially affect cancer susceptibility (see Table 3). For example, a $540 \mathrm{~kb}$ microdeletion at $1 \mathrm{p} 31.1$ was detected in two affected sisters (Figure 1A). Among the genes mapped to this deleted segment, the most relevant to cancer progression is probably ST6GAL$N A C 5$, a sialyltransferase recently reported to mediate breast cancer metastasis to the brain [43]. Another interesting alteration detected in a patient, an approximately $137 \mathrm{~kb}$ deletion at $9 \mathrm{p} 21.3$, encompassed the KIA1797 and the MIR491 genes (Figure 1B). A germline $\mathrm{CNV}$ affecting this genomic segment was recently reported in a colorectal cancer cohort [23]. The finding of a similar 9p21.3 deletion in independent cohorts of cancer patients strengthens their pathogenic role in cancer predisposition.

Our data support the hypothesis that germline DNA $\mathrm{CNV}$ is a genetic factor contributing to breast cancer predisposition, which is in accord with the findings of other studies indicating CNVs as risk factors in cancer, including neuroblastoma [19], colorectal cancer [22,23], hepatocellular carcinoma [44], aggressive prostate cancer [20], nasopharyngeal carcinoma[45] and BRCA1-associated ovarian cancer[38]. Our findings of a possible association of a cancer predisposition phenotype with rare CNVs affecting different genes are in line with the genetic heterogeneity reported in breast cancer. This picture is different from most of the aforementioned studies, which detected recurrent common CNVs associated with cancer risk, except for prostate, colorectal and ovarian cancer $\mathrm{CNV}$ studies, which exhibited high CNV heterogeneity.

\section{Conclusions}

Our analysis of rare CNVs in a small cohort of BRCA1/ $B R C A 2$ mutation-negative breast and/or ovarian cancer families suggests an intriguing excess in the proportion of rare CNVs compared to controls. The future challenge will be to expand sample sizes and to follow cosegregation of given $\mathrm{CNVs}$ with cancer phenotype within families to identify which of the genes involved in the rare CNVs might contribute to familial breast cancer predisposition.

\section{Additional material}

Additional file 1: Supplementary material 1. Description: Clinical parameters of the patients studied, including age at cancer diagnosis, tumor subtype and grade, tumor node metastasis (TNM) stage and immunohistochemistry data.

Additional file 2: Supplementary material 2. Description: Full copy number variation (CNV) data of controls and patients (rare CNVs in bold). Chromosome coordinates are given according to $\mathrm{Hg} 18$.

Additional file 3: Supplementary material 3. Description: Literature review of the genes encompassed by rare copy number variations (CNVs) identified in the patients and reported to be altered in cancer.

Additional file 4: Supplementary material 4. Description: Genomic positions (build 36- $\mathrm{Hg} 18$ ), mapping, type and affected genes of the 23 rare copy number variations identified in controls.

\section{Abbreviations}

bp: base pair; CNV: copy number variation; array-CGH: comparative genomic hybridization on microarray; kb: kilobase; DGV: Database of Genomic Variants; UCSC: University of California Santa Cruz.

\section{Acknowledgements}

This work was supported by grants from the Brazilian National Institute of Science and Technology in Oncogenomics (FAPESP 2008/57887-9 and CNPq 573589/08-9) and FAPESP (2009/00898-1). We thank the Biobank of the AC Camargo Hospital for providing DNA samples. We are indebted to the patients and their families for their participation in the trial.

\section{Author details}

'National Institute of Science and Technology in Oncogenomics, AC Camargo Hospital, Rua Taguá 440, 01508-010, São Paulo, Brazil. ²Department of Genetics and Evolutionary Biology, Institute of Biosciences, University of São Paulo, Rua do Matão 277, 05508-090, São Paulo, Brazil. ${ }^{3}$ Department of Psychiatry, Medicine College, University of São Paulo, Rua Dr Ovídio Pires de Campos 785, 01060-970, São Paulo, Brazil. Institute of Mathematics and Statistics, University of São Paulo, Rua do Matão 1010, 05508-090, São Paulo, Brazil.

\section{Authors' contributions}

ACVK participated in the design of the study, performed part of the molecular genetics analysis and drafted the manuscript. SSC carried out part of the array-CGH experiments. BCGL and DMC carried out the screening for BRCA1/2 mutations. AG carried out the real-time PCR assays for CNV

validation. MIWA was the physician responsible for the clinical trial and the selection and classification of the families and also revised the manuscript. AFN and EMMS participated in the clinical trial and the classification of the families. HB and TMS performed the statistical analysis. RRB and AMVM participated in the design of the study and revised the manuscript. PLP and $C R$ revised the manuscript critically gave their final approval of the version to be published.

\section{Competing interests}

The authors declare that they have no competing interests.

Received: 12 August 2011 Revised: 20 January 2012

Accepted: 7 February 2012 Published: 7 February 2012

\section{References}

1. Fearon ER: Human cancer syndromes: clues to the origin and nature of cancer. Science 1997, 278:1043-1050.

2. Lichtenstein P, Holm NV, Verkasalo PK, lliadou A, Kaprio J, Koskenvuo M, Pukkala E, Skytthe A, Hemminki K: Environmental and heritable factors in the causation of cancer: analyses of cohorts of twins from Sweden, Denmark, and Finland. N Engl J Med 2000, 343:78-85.

3. Chompret A: [Clinical and molecular diagnosis of inherited breastovarian cancer] [in French]. J Gynecol Obstet Biol Reprod (Paris) 2003, 32:101-119.

4. Easton D: Familial risks of cancer. Eur J Cancer 1999, 35:1043-1045.

5. Foulkes WD: Inherited susceptibility to common cancers. N Engl I Med 2008, 359:2143-2153. 
6. Hirshfield KM, Rebbeck TR, Levine AJ: Germline mutations and polymorphisms in the origins of cancers in women. J Oncol 2010, 2010:297671.

7. Conrad DF, Pinto D, Redon R, Feuk L, Gokcumen O, Zhang Y, Aerts J, Andrews TD, Barnes C, Campbell P, Fitzgerald T, Hu M, Ihm CH, Kristiansson K, Macarthur DG, MacDonald JR, Onyiah I, Pang AW, Robson S, Stirrups K, Valsesia A, Walter K, Wei J, Wellcome Trust Case Control Consortium, Tyler-Smith C, Carter NP, Lee C, Scherer SW, Hurles ME: Origins and functional impact of copy number variation in the human genome. Nature 2010, 464:704-712.

8. lafrate AJ, Feuk L, Rivera MN, Listewnik ML, Donahoe PK, Qi Y, Scherer SW, Lee C: Detection of large-scale variation in the human genome. Nat Genet 2004, 36:949-951.

9. Sebat J, Lakshmi B, Troge J, Alexander J, Young J, Lundin P, Månér S, Massa H, Walker M, Chi M, Navin N, Lucito R, Healy J, Hicks J, Ye K, Reiner A, Gilliam TC, Trask B, Patterson N, Zetterberg A, Wigler M: Large-scale copy number polymorphism in the human genome. Science 2004, 305:525-528.

10. Feuk $L$, Carson AR, Scherer SW: Structural variation in the human genome. Nat Rev Genet 2006, 7:85-97.

11. Ng PC, Levy S, Huang J, Stockwell TB, Walenz BP, Li K, Axelrod N, Busam DA, Strausberg RL, Venter JC: Genetic variation in an individual human exome. PLoS Genet 2008, 4:e1000160.

12. Stankiewicz $P$, Lupski JR: Structural variation in the human genome and its role in disease. Annu Rev Med 2010, 61:437-455.

13. Stranger BE, Forrest MS, Dunning M, Ingle CE, Beazley C, Thorne N, Redon R, Bird CP, de Grassi A, Lee C, Tyler-Smith C, Carter N, Scherer SW, Tavaré S, Deloukas $P$, Hurles ME, Dermitzakis ET: Relative impact of nucleotide and copy number variation on gene expression phenotypes Science 2007, 315:848-853.

14. Bunyan DJ, Eccles DM, Sillibourne J, Wilkins E, Thomas NS, Shea-Simonds J, Duncan PJ, Curtis CE, Robinson DO, Harvey JF, Cross NC: Dosage analysis of cancer predisposition genes by multiplex ligation-dependent probe amplification. Br J Cancer 2004, 91:1155-1159.

15. Casilli F, Tournier I, Sinilnikova OM, Coulet F, Soubrier F, Houdayer $C$ Hardouin A, Berthet P, Sobol H, Bourdon V, Muller D, Fricker JP, CapouladeMetay C, Chompret A, Nogues C, Mazoyer S, Chappuis P, Maillet P, Philippe C, Lortholary A, Gesta P, Bézieau S, Toulas C, Gladieff L, Maugard CM, Provencher DM, Dugast C, Delvincourt C, Nguyen TD Faivre $L$, et al: The contribution of germline rearrangements to the spectrum of BRCA2 mutations. J Med Genet 2006, 43:e49.

16. Petrij-Bosch A, Peelen $T$, van Vliet $M$, van Eijk R, Olmer R, Drüsedau M, Hogervorst FB, Hageman S, Arts PJ, Ligtenberg MJ, Meijers-Heijboer $H$ Klijn JG, Vasen HF, Cornelisse CJ, van 't Veer LJ, Bakker E, van Ommen GJ, Devilee P: BRCA1 genomic deletions are major founder mutations in Dutch breast cancer patients. Nat Genet 1997, 17:341-345.

17. Kuiper RP, Ligtenberg MJ, Hoogerbrugge N, Geurts van Kessel A: Germline copy number variation and cancer risk. Curr Opin Genet Dev 2010, 20:282-289.

18. Shlien A, Baskin B, Achatz MI, Stavropoulos DJ, Nichols KE, Hudgins L, Morel CF, Adam MP, Zhukova N, Rotin L, Novokmet A, Druker H, Shago M, Ray PN, Hainaut P, Malkin D: A common molecular mechanism underlies two phenotypically distinct 17p13.1 microdeletion syndromes. Am J Hum Genet 2010, 87:631-642.

19. Diskin SJ, Hou C, Glessner JT, Attiyeh EF, Laudenslager M, Bosse K, Cole K, Mossé YP, Wood A, Lynch JE, Pecor K, Diamond M, Winter C, Wang K, Kim C, Geiger EA, McGrady PW, Blakemore Al, London WB, Shaikh TH, Bradfield J, Grant SF, Li H, Devoto M, Rappaport ER, Hakonarson H, Maris JM: Copy number variation at 1q21.1 associated with neuroblastoma. Nature 2009, 459:987-991.

20. Liu W, Sun J, Li G, Zhu Y, Zhang S, Kim ST, Sun J, Wiklund F, Wiley K, Isaacs SD, Stattin P, Xu J, Duggan D, Carpten JD, Isaacs WB, Grönberg H, Zheng SL, Chang BL: Association of a germ-line copy number variation at 2 p24.3 and risk for aggressive prostate cancer. Cancer Res 2009, 69:2176-2179.

21. Lucito R, Suresh S, Walter K, Pandey A, Lakshmi B, Krasnitz A, Sebat J, Wigler M, Klein AP, Brune K, Palmisano E, Maitra A, Goggins M, Hruban RH: Copy-number variants in patients with a strong family history of pancreatic cancer. Cancer Biol Ther 2007, 6:1592-1599.

22. Thean LF, Loi C, Ho KS, Koh PK, Eu KW, Cheah PY: Genome-wide scan identifies a copy number variable region at $3 q 26$ that regulates PPM1L in APC mutation-negative familial colorectal cancer patients. Genes Chromosomes Cancer 2010, 49:99-106

23. Venkatachalam R, Verwiel ET, Kamping EJ, Hoenselaar E, Görgens H, Schackert HK, van Krieken JH, Ligtenberg MJ, Hoogerbrugge N, van Kessel AG, Kuiper RP: Identification of candidate predisposing copy number variants in familial and early-onset colorectal cancer patients. Int J Cancer 2011, 129:1635-1642

24. Yoshihara K, Tajima A, Adachi S, Quan J, Sekine M, Kase H, Yahata T, Inoue I, Tanaka K: Germline copy number variations in BRCA1-associated ovarian cancer patients. Genes Chromosomes Cancer 2011, 50:167-177.

25. National Comprehensive Cancer Network. [http://www.nccn.org/].

26. Krepischi-Santos AC, Rajan D, Temple IK, Shrubb V, Crolla JA, Huang S, Beal S, Otto PA, Carter NP, Vianna-Morgante AM, Rosenberg C: Constitutional haploinsufficiency of tumor suppressor genes in mentally retarded patients with microdeletions in 17p13.1. Cytogenet Genome Res 2009, 125:1-7.

27. Krepischi AC, Knijnenburg J, Bertola DR, Kim CA, Pearson PL, Bijlsma E, Szuhai K, Kok F, Vianna-Morgante AM, Rosenberg C: Two distinct regions in 2q24.2-q24.3 associated with idiopathic epilepsy. Epilepsia 2010, $51: 2457-2460$

28. Allemeersch J, Van Vooren S, Hannes F, De Moor B, Vermeesch JR, Moreau Y: An experimental loop design for the detection of constitutional chromosomal aberrations by array CGH. BMC Bioinformatics 2009, 10:380.

29. Livak KJ, Schmittgen TD: Analysis of relative gene expression data using real-time quantitative PCR and the $2^{-\Delta \Delta C}$ method. Methods 2001, 25:402-408.

30. Database of Genomic Variants. [http://projects.tcag.ca/variation/]

31. UCSC Genome Browser. [http://genome.ucsc.edu/].

32. BioMart. [http://www.ensembl.org/biomart/martview/ a4c96f57a539d313f74223bb4719aedf].

33. Gene Ontology Tree Machine software, Gene Set Analysis Toolkit version 2. [http://bioinfo.vanderbilt.edu/webgestalt/]

34. Zhang B, Schmoyer D, Kirov S, Snoddy J: GOTree Machine (GOTM): a webbased platform for interpreting sets of interesting genes using Gene Ontology hierarchies. BMC Bioinformatics 2004, 5:16.

35. Jakobsson M, Scholz SW, Scheet P, Gibbs JR, VanLiere JM, Fung HC, Szpiech ZA, Degnan JH, Wang K, Guerreiro R, Bras JM, Schymick JC, Hernandez DG, Traynor BJ, Simon-Sanchez J, Matarin M, Britton A, van de Leemput J, Rafferty I, Bucan M, Cann HM, Hardy JA, Rosenberg NA, Singleton $A B$ : Genotype, haplotype and copy-number variation in worldwide human populations. Nature 2008, 451:998-1003.

36. Perry GH, Ben-Dor A, Tsalenko A, Sampas N, Rodriguez-Revenga L, Tran CW Scheffer A, Steinfeld I, Tsang P, Yamada NA, Park HS, Kim JI, Seo JS, Yakhini Z, Laderman S, Bruhn L, Lee C: The fine-scale and complex architecture of human copy-number variation. Am J Hum Genet 2008, 82:685-695.

37. Pinto D, Darvishi $K$, Shi $X$, Rajan D, Rigler D, Fitzgerald T, Lionel AC, Thiruvahindrapuram B, MacDonald JR, Mills R, Prasad A, Noonan K, Gribble S, Prigmore E, Donahoe PK, Smith RS, Park JH, Hurles ME, Carter NP, Lee C, Scherer SW, Feuk L: Comprehensive assessment of array-based platforms and calling algorithms for detection of copy number variants. Nat Biotechnol 2011, 29:512-520.

38. White SJ, Vissers LE, Geurts van Kessel A, de Menezes RX, Kalay E, Lehesjoki AE, Giordano PC, van de Vosse E, Breuning MH, Brunner HG, den Dunnen JT, Veltman JA: Variation of CNV distribution in five different ethnic populations. Cytogenet Genome Res 2007, 118:19-30

39. Mkrtchyan H, Gross M, Hinreiner S, Polytiko A, Manvelyan M, Mrasek K, Kosyakova N, Ewers E, Nelle H, Liehr T, Bhatt S, Thoma K, Gebhart E, Wilhelm S, Fahsold R, Volleth M, Weise A: The human genome puzzle: the role of copy number variation in somatic mosaicism. Curr Genomics 2010, 11:426-431.

40. Shlien A, Malkin D: Copy number variations and cancer susceptibility. Curr Opin Oncol 2010, 22:55-63.

41. Korbel JO, Urban AE, Grubert F, Du J, Royce TE, Starr P, Zhong G, Emanuel BS, Weissman SM, Snyder M, Gerstein MB: Systematic prediction and validation of breakpoints associated with copy-number variants in the human genome. Proc Natl Acad Sci USA 2007, 104:10110-10115.

42. Yoshihara K, Tajima A, Adachi S, Quan J, Sekine M, Kase H, Yahata T, Inoue I, Tanaka K: Germline copy number variations in BRCA1-associated ovarian cancer patients. Genes Chromosomes Cancer 2011, 50:167-177. 
43. Bos PD, Zhang XH, Nadal C, Shu W, Gomis RR, Nguyen DX, Minn AJ, van de Vijver MJ, Gerald WL, Foekens JA, Massagué J: Genes that mediate breast cancer metastasis to the brain. Nature 2009, 459:1005-1009.

44. Clifford RJ, Zhang J, Meerzaman DM, Lyu MS, Hu Y, Cultraro CM, Finney RP, Kelley JM, Efroni S, Greenblum SI, Nguyen CV, Rowe WL, Sharma S, Wu G, Yan C, Zhang H, Chung YH, Kim JA, Park NH, Song IH, Buetow KH: Genetic variations at loci involved in the immune response are risk factors for hepatocellular carcinoma. Hepatology 2010, 52:2034-2043.

45. Tse KP, Su WH, Yang ML, Cheng HY, Tsang NM, Chang KP, Hao SP, Yao SY, Chang YS: A gender-specific association of CNV at 6p21.3 with NPC susceptibility. Hum Mol Genet 2011, 20:2889-2896.

doi:10.1186/bcr3109

Cite this article as: Krepischi et al: Germline DNA copy number

variation in familial and early-onset breast cancer. Breast Cancer Research 2012 14:R24

\section{Submit your next manuscript to BioMed Central} and take full advantage of:

- Convenient online submission

- Thorough peer review

- No space constraints or color figure charges

- Immediate publication on acceptance

- Inclusion in PubMed, CAS, Scopus and Google Scholar

- Research which is freely available for redistribution

Submit your manuscript at www.biomedcentral.com/submit 